\title{
Intracorneal Inlays - Special Focus on the Raindrop
}

\author{
José L Güell ${ }^{1}$ and Omar A Barrada 2,3
}

1. Director, Cornea and Refractive Surgery Unit, Ocular Microsurgery Institute, Barcelona and Associate Professor of Ophthalmology, Autonoma University of Barcelona, Barcelona, Spain; 2. Fellow, Cornea and Refractive Surgery Unit, Ocular Microsurgery Institute, Barcelona and Autonoma University of Barcelona, Barcelona, Spain; 3. Consultant Ophthalmogist, Ophthalmology Department, Cairo University Medical School, Cairo, Egypt

\begin{abstract}
Presbyopia remains the last frontier for refractive surgeons. With increased demand for spectacle independence at all ages, ophthalmologists are exploring different approaches for presbyopia correction. The idea of adding synthetic material to the cornea for the management of presbyopia has come a long way since its inception. The Raindrop ${ }^{\circledR}$ (ReVision Optics ${ }^{\circledR}$ ), KAMRATM Inlays (AcuFocus ${ }^{\mathrm{TM}}$ ) and the Flexivue Microlens $^{\mathrm{TM}}$ (Presbia ${ }^{\mathrm{TM}}$ ) are three very different inlays that attempt to reverse presbyopia through different mechanisms. The Raindrop changes the curvature of the anterior cornea in the plane of the pupil, the Kamra uses the principle of the pinhole to increase depth of focus, while the Flexivue is a refractive annular add lenticule that creates a paracentral zone for near vision. The decreased incidence of complications, ease of insertion, reversibility and potential applicability to patients with various refractive statuses make inlays a powerful addition to the armamentarium in the management of presbyopia.
\end{abstract}

\section{Keywords}

Corneal inlays, presbyopia, Raindrop, review

Disclosure: The authors have no conflicts of interest to declare.

Received: 10 January 2014 Accepted: 19 March 2014 Citation: European Ophthalmic Review, 2014;8(1):23-30 DOI: 10.17925/EOR.2014.08.01.23 Correspondence: José L Güell, Director, Cornea and Refractive Surgery Unit, Instituto Microcirugia Ocular of Barcelona, C/ Josep Mª Lladó 3, 08035 Barcelona, Spain. E: guell@imo.es

Patient demand for spectacle independence is growing. The advances in laser and non-laser technology have allowed ophthalmologists to offer their patients the freedom to choose between depending on their glasses, or to go spectacle free. Presbyopia, defined as the age-related loss of the ability to clearly accommodate onto near objects, has become the last frontier for refractive vision correction.

The complexity and illusiveness of presbyopia necessitates the ophthalmologist to tackle its pathology in different ways. Corneal, lenticular and even scleral approaches have been previously explored in an attempt to reverse this age-related phenomenon. Corneal monovision and presbyopic laser-assisted in situ keratomileusis (presbyLASIK) procedures give conflicting results. Monovision gives the patient near vision on the expense of far and binocular vision; while presbyLASIK requires further development in its nomogram in order to achieve consistent postoperative results. ${ }^{1-3}$ Conductive keratoplasty, a technique in which the cornea is moulded into a new shape using radiofrequency waves, has also been studied as an option for presbyopia treatment, with patients usually experiencing a large overcorrection followed by a significant regression of their refractive outcome overtime. ${ }^{4}$

Other procedures described in the management of presbyopia include scleral expansion and anterior sclerotomy techniques.5,6 Lens surgery with implantation of multifocal or accommodating intraoperative lenses (IOLS) have also shown to reduce dependence on reading glasses; $;$ however, risks associated with intraocular surgery, difficulty in lens exchange, biometric errors, patient dissatisfaction and loss in contrast sensitivity and photopic phenomena make them far from perfect. ${ }^{8}$ Also, there is an age bracket (40-50 years old) where patients might be experiencing presbyopia symptoms but still had not developed cataract, and in these patients lens surgery is probably less than ideal. Pseudophakic patients with monofocal IOLs are also not eligible for secondary lens implantation, and in these patients an intracorneal inlay might be a good option.

One of the earliest proposed methods for presbyopia correction is additive refractive keratoplasty. This term refers to procedures in which a foreign material is added to the corneal tissue to modify the refractive condition of the eye. Albeit this method is not new, recent advances in technology, its potential for reversibility and ease of application has made it a subject of great interest to ophthalmologists in recent years. ${ }^{9}$

\section{History}

As mentioned, intracorneal inlays are far from being a novel idea. José I. Barraquer performed experiments with corneal implants as early as 1949, although with unsatisfactory results. ${ }^{10}$ Since then, this refractive technology has undergone a series of improvements.

Early inlays were composed of flint glass and plexiglass for the correction of aphakia and high myopia. Earlier trials attempted to use poly(methyl methacrylate) (PMMA) and polysulfone inlays to treat high myopia. ${ }^{11} \mathrm{High}$ index polymers were an optically attractive material choice; however, poor permeability limited their use. As a result, Barraquer developed 


\section{Figure 1: Kamra Inlay in vitro 22}

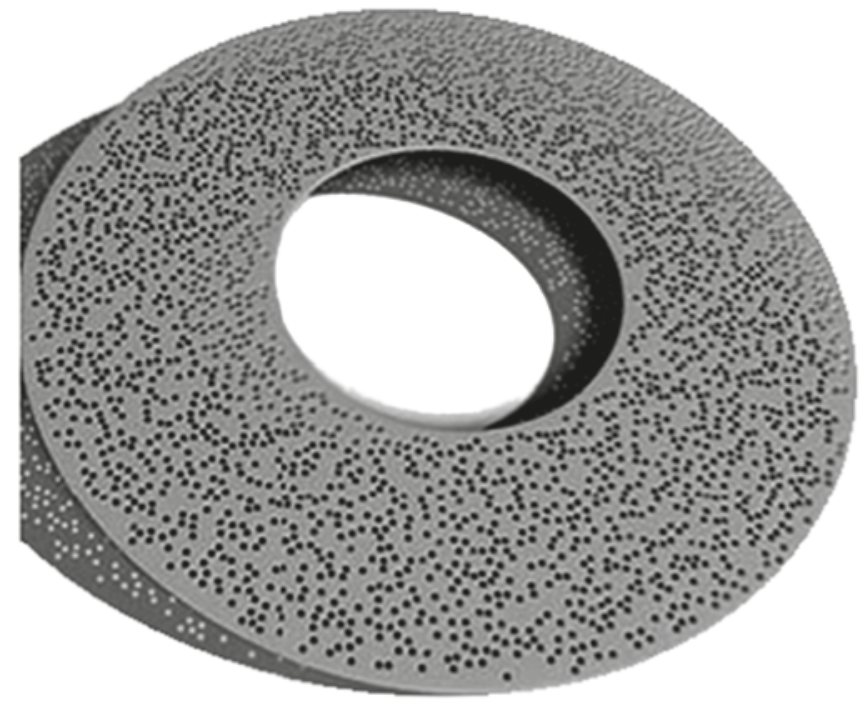

Figure 2: Kamra Inlay in vivo ${ }^{23}$

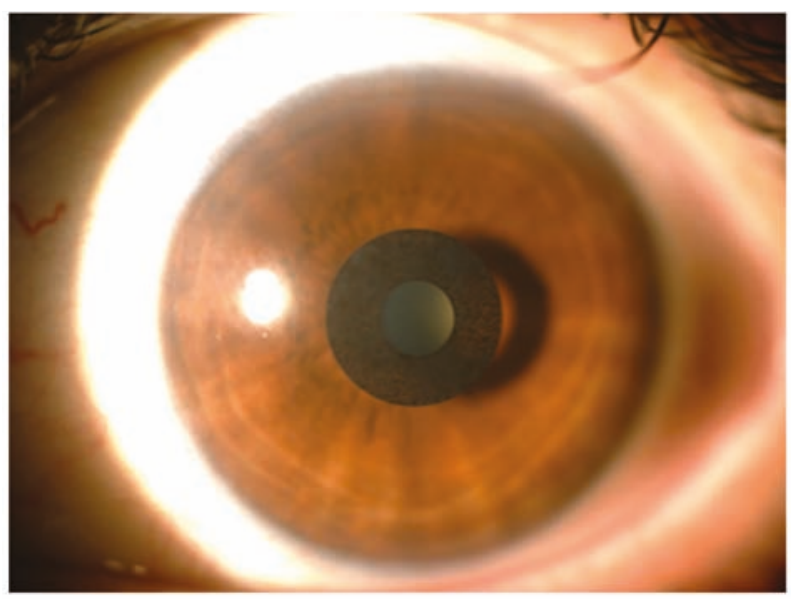

human donor stromal lenticules for inlays (keratophakia) and onlays (epikeratophakia). Claes H Dohlman was the first to describe the use of a permeable lenticule in $1967 .{ }^{12}$ Hydrogel inlays were developed so as not to impede metabolic gradients across the stroma including nutrient flow to the anterior cornea. Although semipermeable hydrogel polymers allow free nutrient flow, they have a relatively low index of refraction and are therefore limited in optical power.

Past inlay designs include the Kerato-GelTM (Allergan, Inc., Irvine, California), which was designed for aphakia and was composed of lidofilcon A. The Chiron inlay ${ }^{\circledR}$ (Bausch + Lomb, Rochester, New York) was a meniscus hydrogel optical lens that ranged from 1.50 to 3.50 diopter (D) in add power with a diameter ranging from 1.8 to $2.2 \mathrm{~mm}$. The PermaVision Intracorneal Lens ${ }^{\circledR}$ (Anamed, Lake Forest, California) was composed of a hydgrogel-based material called Nutrapore with a water content of $78 \%$. This lens, measuring 5.0 to $5.5 \mathrm{~mm}$ in diameter with a central thickness of 30 to $60 \mu \mathrm{m}$, intentionally altered the anterior surface curvature. This was followed by the IntraLens (now ReVision Optics ${ }^{\circledR}$, Inc. Lake Forest, California) in the evolution of space-occupying lenticules that intentionally altered the surface curvature to create a kind of multifocal cornea for the treatment of hyperopia and presbyopia. These technologies served as the precursor for the Raindrop inlay (formerly the Vue+ and PresbyLens, ReVision Optics, Inc.). The Intracorneal Microlens' ${ }^{\mathrm{TM}}$ (BioVision AG, Brüggs, Switzerland) was a $3 \mathrm{~mm}$ diameter, $20 \mu \mathrm{m}$ thick hydrogel annular add inlay with a central opening free of optical power that also allowed nutrient flow to the anterior central cornea. This inlay was designed for placement in a stromal pocket with a mechanical microkeratome pocket maker. The Microlens went on to be known as the InVue ${ }^{\mathrm{TM}}$, the precursor to the Flexivue inlay ${ }^{\mathrm{TM}}$ (Presbia Coöperatief UA, Amsterdam, the Netherlands ). ${ }^{13}$

\section{The Problem with Corneal Inlays}

In order for the cornea to function properly its distinct traits must be maintained. The cornea must remain transparent in order for light rays to enter the eye. This transparency is achieved because of the avascular structure of the cornea, the scarcity of cells within its stroma, its unmyelinated nerve fibres, its relative state of dehydration and, most importantly, the precise arrangement of its collagen fibrils. Corneal stromal fibrils have a characteristically narrow diameter and are aligned in parallel arrays and immersed in specialised clusters of proteoglycans. ${ }^{14-16}$ The corneal stroma undergoes homeostatic remodelling via the functions performed by keratocytes and possibly other cell types, including bone marrow-derived cells and myofibroblasts. Keratocytes are responsible for the production and maintenance of the extracellular matrix of the corneal stroma. ${ }^{17}$ Changes in environmental conditions, such as an intrastromal implant, may modulate the keratocyte phenotype, resulting in functional changes in gene expression, contractility, matrix production and other characteristics that contribute to the wound-healing response. Therefore, the goal of successful inlay design, implantation technique and perioperative care is to minimise or eliminate the potential changes induced by the introduction of this foreign material into the cornea. ${ }^{18}$

The cornea, besides being an avascular structure, is also considered a very special tissue because of how it receives both its oxygen and nutrients indirectly by diffusion either from the aqueous humour posteriorly or from the pre-corneal tear film anteriorly. Any insult to the cornea that significantly affects those distinctive properties will interfere with its function with subsequent affect vision. ${ }^{18-20}$

Inlays should be semipermeable, allowing oxygen supplied from the tear film and glucose supplied from the aqueous humour to nourish the vital corneal cells while also allowing catabolic end products to be delivered to the aqueous humour. This mechanism is essential to prevent anterior stromal necrosis and corneal oedema, which plagued older attempts at placing an inlay within the corneal stroma. ${ }^{13}$

This problem with older inlay models was clearly demonstrated by Mulet and his co-workers where 34 hyperopic eyes were implanted with a hydrogel intra-corneal inlay (PermaVision ${ }^{\circledR}$ ) where they came to a conclusion that intra-corneal inlays was a good option for treating hyperopia, but that the tested inlay caused significant visual loss and scarring and had to be explanted in the majority of cases. ${ }^{21}$

Another practical problem that all commercially available inlays share is that they rely entirely on pupillary size. Even though all three inlays aim to reduce presbyopia symptoms through very different mechanisms, they all work through improving the image formed through the narrowed pupil. Therefore as soon as the pupil becomes larger than the outer diameter of each inlay, the effect of improving unaided near vision decreases dramatically. 
Mechanism of Action of Modern Corneal Inlays

The three modern corneal inlays that are being investigated and used commercially are: the Raindrop (Revision Optics ${ }^{\circledR}$ ), Kamra Inlay (Acufocus, Inc. previously known as the $\mathrm{ACl} 7000$ ) and the Flexivue Microlens (Presbia). These three inlays are designed in very different ways in attempt to reach the same goal: to allow the presbyope to see near objects without the need for his or her glasses.

\section{The Kamra Inlay}

The near synkinesis is composed of accommodation, convergence and miosis. It has been proved that narrowing of the pupillary aperture improves depth of focus and aids in improving near vision even when accommodation is kept constant. The Kamra Inlay utilises the latter part of this synkinesis in an attempt to improve near vision in presbyopes. ${ }^{20}$

The Kamra Inlay is a $10.0 \mu \mathrm{m}$ thin microperforated artificial aperture, with a $3.8 \mathrm{~mm}$ outer diameter with a central aperture (inner diameter) of $1.6 \mathrm{~mm}$. The Kamra Inlay is made of polyvinylidene fluoride (PVDF), which is biocompatible in vitro, and pigmented with nanoparticles of carbon to make the inlay opaque (see Figure 1). This permeable material has a light transmission of $5 \%$. The inlay has a pseudorandom microperforation pattern consisting of 8,400 holes ranging in size from 5 to $11 \mathrm{~mm}$ in diameter to allow water and nutrition flow to prevent corneal thinning and epithelial decompensation. There is no refractive power in the central aperture. The inlay design blocks unfocused light, allowing only focused light to enter the eye through the central aperture, resulting in decreased retinal blur and increased depth of focus, which results in a minimal effect on distance image quality while improving near image quality. The Kamra Inlay is centred on the line of sight of the nondominant eye after the creation of a corneal flap using a femtosecond laser at a depth of approximately $200 \mathrm{~mm}$ (see Figure 2). ${ }^{22}$

Yilmaz et al. in Turkey published a paper on the long-term results of the Kamra Inlay, demonstrating the inlay's performance. The study enrolled 39 patients aged 45 to 60 years. At 4-year follow-up, all patients had 2 or more lines of improvement in uncorrected near visual acuity (UNVA) with no significant loss in distance vision. The mean final UNVA was 20/20 (Jaeger [J1]); $96 \%$ of patients could read J3 or better. The uncorrected distance acuity was 20/40 or better in all eyes. ${ }^{23}$

\section{The Flexivue Microlens}

The Flexivue Microlens (Presbia Coöperatief UA) works through corneal multifocality by changing the refractive power of the central cornea to improve near vision performance. It is a transparent, hydrophilic concave-convex disc, manufactured from an optically clear copolymer of hydroxyethylmethacrylate and methylmethacrylate containing an ultraviolet blocker. The inlay has a $3 \mathrm{~mm}$ diameter and a thickness of approximately 15 to $20 \mu \mathrm{m}$, depending on the additional power, which acts by changing the refractive index of the cornea. The micro-lens material has a refractive index of 1.4583 and has a light transmission of $95 \%{ }^{24}$

The central $1.8 \mathrm{~mm}$ diameter of the disc is plano with no power and the peripheral zone has the required additional power for near vision. The available inlay refractive power ranges from +1.25 $\mathrm{D}$ to $+3.50 \mathrm{D}$ in $0.25 \mathrm{D}$ increments. At the centre of the disc, a $0.15 \mathrm{~mm}$ diameter hole allows for the transfer of oxygen and nutrients into the cornea through the lens (see Figure 3).

During distance vision, rays passing through the optically neutral central zone of the implant and the free peripheral corneal tissue will bring the
Figure 3: Showing the Dimensions of the Flexivue Intracorneal Inlay ${ }^{24}$

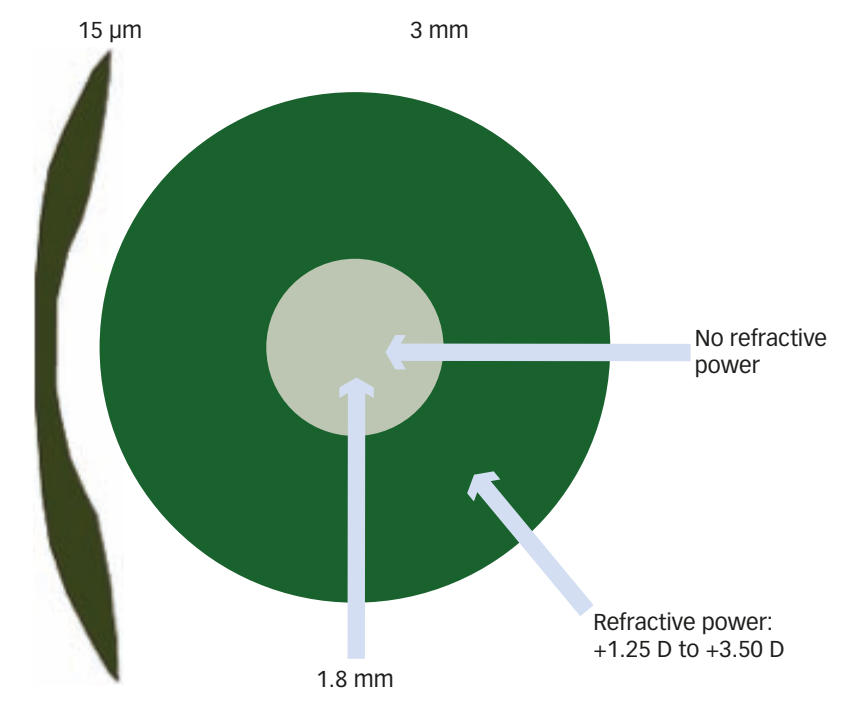

Figure 4: Flexivue in Place Seen by

Retro-illumination ${ }^{24}$

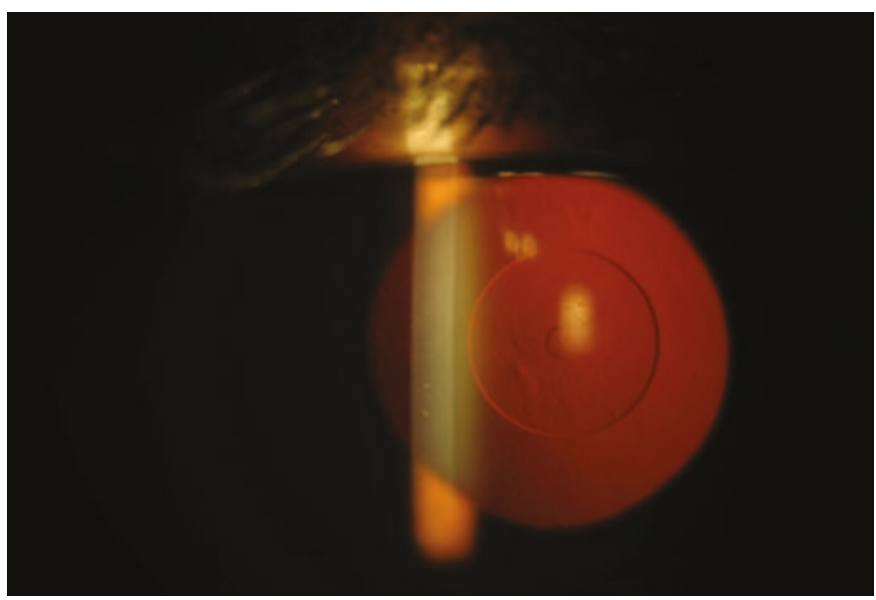

image of regard into focus on the retina. Whereas rays that pass through the refractive peripheral zone of the inlay will be focused in front of the retina. Conversely, during near vision, rays passing through the central zone of the implant will be out of focus behind the retina and rays passing through the peripheral clear cornea will be blocked by the pupil, while the rays passing through the peripheral refractive zone of the inlay will be focused on the retina - allowing for clear near vision. ${ }^{23}$

The inlay is inserted via a special injector in a corneal pocket created using a femtosecond laser to a depth of approximately 280-300 mm with a diameter of $9.0 \mathrm{~mm}$. The inlay is centred onto the line of sight using the microscope and centration device of the microscope (see Figure 4).

Limnopoulou and co-workers, assessing the ability of the Flexivue to improve presbyopia symptoms in 47 emmetropic patients, showed that at 12 months after surgery, mean UNVA significantly improved from $0.68 \pm 0.03 \log$ MAR (20/100) (range 0.40 to 1.00 [20/50 to 20/200]) to $0.14 \pm 0.09 \log$ MAR (20/25) (range -0.02 to 0.36 [20/12 to 20/50]) ( $p<0.001)$ in operated eyes, and from $0.53 \pm 0.13 \log M A R(20 / 60)$ (range 0.34 to 0.73 [20/40 to 20/100]) preoperatively to $0.13 \pm 0.13 \log$ MAR (20/25) (range 0.00 to $0.38[20 / 20$ to $20 / 50]$ ) binocularly $(p<0.001)$. Mean UDVA in operated 


\section{Figure 5: Showing the Dimensions of the Raindrop Inlay ${ }^{25}$}

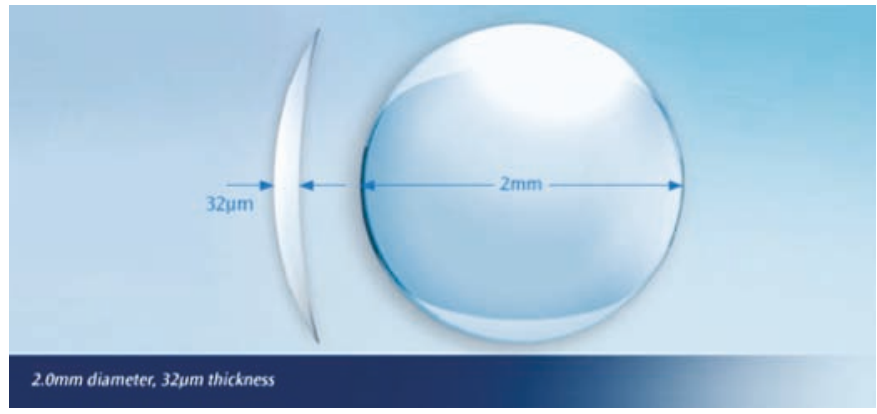

Figure 6: Showing the Raindrop in vivo ${ }^{26}$

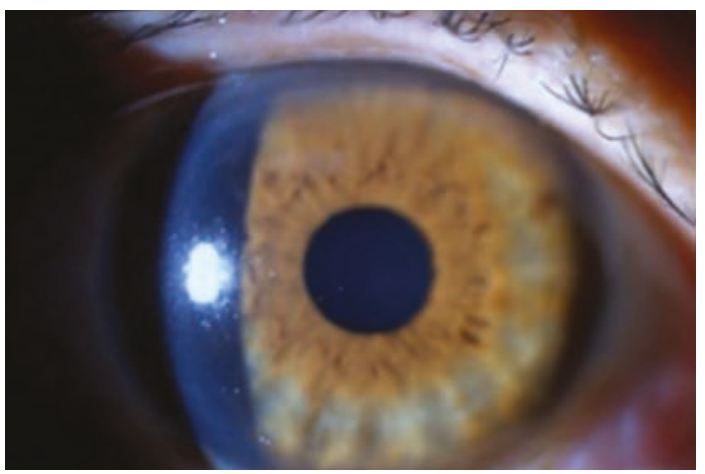

eyes significantly decreased from $0.06 \pm 0.09 \log$ MAR (20/25) (range -0.08 to 0.26 [20/16 to $20 / 40]$ ) preoperatively to $0.38 \pm 0.15 \log$ MAR (20/50) (range 0.12 to 0.8 [20/25 to $20 / 125])(p<0.001)$, whereas binocularly it did not change significantly $(\mathrm{p}=0.516) .^{24}$

\section{The Raindrop}

The Raindrop corneal inlay is made of a clear, permeable hydroge material that has the same refractive index as the cornea (1.376). The inlay has a positive meniscus shape, with a diameter of $2 \mathrm{~mm}$ and a central thickness of $32 \mu \mathrm{m}$. The inlay has no intrinsic refractive power because it has the same refractive index of the surrounding corneal tissue (see Figure 5). The inlay works through altering the refractive power of the eyes by increasing the central radius of curvature of the cornea directly overlying the implant. The inlay is thinner at the edge than at the centre, allowing for a smooth transition in the corneal anterior radius of curvature from the area directly overlying the inlay, to the midzone then finally to the unaltered peripheral cornea. The permeability of the hydrogel material used to manufacture this inlay insures free passage of oxygen and nutrients across it, thus preventing unwanted side effects such as stromal and epithelial oedema. ${ }^{25}$

The Raindrop aims to increase the refractive power of the non-dominant eye at the centre of the pupil. The smooth transition from the centre of the inlay to its periphery, coupled with its relatively shallow placement in the cornea $(130 \mu \mathrm{m})$, allow for a subtle monovision by increasing prolacity and/or positive asphericity, which allow the patient to focus clearly for near vision, while minimally affecting monocular distance vision. The Raindrop is placed in the line of sight using the target of the microscope for fixation. The corneal flap is fashioned using a femtosecond laser to ensure accurate placement of the inlay at the optimum depth, followed by precise positioning of the preloaded inlay directly onto the line of sight of the light-constricted pupil (see Figure 6).
Table 1: Showing Pre- and Post-operative Visual Performance with the Raindrop ${ }^{25}$

\begin{tabular}{llllll} 
& \multicolumn{5}{l}{ Mean (Snellen 20/x) \pm SD (LogMAR) } \\
Preop. & Postop. & Preop. & Postop. & Preop. & Postop. \\
monocular & monocular & monocular & monocular & binocular & binocular \\
UNVA & UNVA & UDVA & UDVA & UDVA & UDVA \\
$132 \pm 0.15$ & $21 \pm 0.04$ & $68 \pm 0.17$ & $31 \pm 0.14$ & $53 \pm 0.22$ & $19 \pm 0.11$
\end{tabular}

UDVA = uncorrected distance visual acuity; UNVA = uncorrected near visual acuity.

To date there have been two published, peer-reviewed articles that demonstrate the efficacy of the Raindrop in reversing amblyopia..25,26 Both papers assess the inlay's ability to improve UNVA with further analysis of the potential adverse effects that might accompany such an attempt. Effects on both corrected and uncorrected distance vision, contrast sensitivity, visual performance at near, intermediate and distances and patients' satisfaction were studied.

The study by Chayet and co-workers enrolled 16 hyperopic patients who concomitantly suffered from presbyopia and examined the ability of Raindrops to improve near vision following laser corneal correction of the hyperopia. By 1 day postoperatively, the eyes with the inlay had statistically significantly improved UNVA over the preoperative value $(p<10-11)$. The mean near acuity ranged between 20/21 and 20/25 at all visits from 1 week onwards, with a statistically significant improvement over preoperative values at all visits $(p<10-10)$. The improvement in the mean UDVA from preoperatively to the 1-week follow-up onwards was statistically significant $(\mathrm{p}<0.0001)$. By 12 months postoperatively, all 14 patients analysed had a UNVA of 20/25 or better in the eye with the inlay. At 12 months, one patient had a UDVA of 20/63, which improved to 20/40 when the patient returned for an informal 2-year visit. All other patients had a UDVA of 20/40 or better. ${ }^{25}$

Mean monocular and binocular UNVA was 20/27 or better at all visits, with a mean binocular UDVA that had improved significantly from 20/53 before surgical intervention to 20/19 postoperatively (see Table 1).

The second paper by Garza et al. showed that the Raindrop implant achieved the effectiveness endpoint from 1 day postoperatively and was shown to be a statistically significant improvement relative to preoperatively $\left(p=1.1 \times 10^{-7}\right)$. Mean acuity was between 0.04 and $0.07 \log$ MAR (20/22 to 20/23 Snellen) at all visits from 1 week onwards. Statistical analysis again showed improvement relative to postoperatively $\left(p<10^{-11}\right)$ for all visits). When chronologically adjacent visits were compared, near vision was shown to have stabilised at 1-week because the $p$ value for the 1-week to 1-month acuity change was greater than 0.5 , as were all subsequent comparisons.

By 1 month postoperatively mean binocular UNVA was 0.03 IogMAR (20/21 Snellen) (standard deviation $[S D]=0.1)$ and remained less than 0.1 logMAR (20/25 Snellen) at all subsequent postoperative visits. By 1 month postoperatively (first measurement), mean binocular UDVA was 0.01 $\operatorname{logMAR}(20 / 20$ Snellen) $(\mathrm{SD}=0.05)$ and remained at this level or better at all subsequent postoperative visits. No patient lost 0.2 logMAR corrected visual acuity at near or distance in the implanted eye during any examination. ${ }^{26}$

Patients in both studies were asked to perform certain tasks that are usually done at both near and intermediate distances. Their performance pre- and post-Raindrop implantation was compared with all patients showing a significant improvement in task performance post inlay implantation (see Table 2). Also, visual symptoms (glare, halos, blurred 
vision, double vision and fluctuation in vision) were analysed using a scale. At 12 months, none of the 36 patients involved in both studies reported any increase in subjective experience of such phenomenon, while performance of the visual tasks had clearly improved. ${ }^{26}$

\section{Conclusion}

Intracorneal inlay implantation has become a topic of great interest to ophthalmologists. Not only have studies shown their efficiency in treating presbyopia, but also the extra-ocular nature of the procedure, ease of insertion and potential for reversibility make the latest commercially available models very appealing.

Commercially available inlays (Raindrop, Flexivue and Kamra) function through different mechanisms, with all three inlays showing the ability to reverse presbyopia symptoms. Which inlay works best for which type of patient is yet to be determined.
1. Epstein RL, Gurgos MA, Presbyopia treatment by monocular peripheral presbyLASIK, J Refract Surg 2009;25:516-23.

2. Braun EH, Lee J, Steinert RF, Monovision in LASIK, Ophthalmology, 2008:115:1196-1202.

3. Alió JL, Amparo F, Ortiz D, Mopreno L, Corneal multifocality with excimer laser for presbyopia correction, Curr Opin Ophthalmol, 2009:20:264-71.

4. Ehrlich JS, Manche EE, Regression of effect over long-term follow-up of conductive keratoplasty to correct mild to moderate hyperopia, J Cataract Refract Surg, 2009;35:1591-6.

5. Malecaze FJ, Gazagne CS, Tarroux MC, Gorrand JM, Scleral expansion bands for presbyopia, Ophthalmology 2001; 108:2165-71

6. Qazi MA, Pepose JS, Shuster JJ, Implantation of scleral expansion band segments for the treatment of presbyopia Am J Ophthalmol, 2002;134:808-15.

7. Maxwell WA, Waycaster CR, D'Souza AO, et al., A United States cost-benefit comparison of an apodized, diffractive presbyopia-correcting multifocal intraocular lens and a conventional monofocal lens, J Cataract Refract Surg 2008;34:1855-61.

8. Woodward MA, Randleman JB, Stulting RD, Dissatisfaction after multifocal intraocular lens implantation, I Cataract after multifocal intraocular lens

9. Barraquer Jl, Modification of refraction by means of intracorneal inclusion, Int Ophthalmol Clin, 1966;6:53-78 intracorneal inclusion, Int Ophthalmol Clin, 1966;6:
0. Barraquer J. Queratoplatica Refractiva. Estudios e informaciones, Oftalmologicas, 1949;2:10

11. Deg JK, Binder PS, Histopathology and clinical behavior of polysulfone intracorneal implants in the baboon model. Polysulfone lens implants, Ophthalmology, 1988:95:506-15.

12. Dohlman $\mathrm{CH}$, Refojo MF, Rose J, Synthetic polymers in corneal surgery: glyceryl methacylate, Arch Ophthalmol 1967;177:52-8

13. Waring GO, IV Santhiago MR, The evolution of corneal inlays-Exploring the development of intrastromal inlays for the treatment of presbyopia, Cataract \& Refractive Surgery Today, December 2011. Available at: http://bmctoday.net/ crstodayeurope/2011/12/article.asp?f=the-evolution-of corneal-inlays (accessed March 27, 2014).

14. Dohlman $\mathrm{CH}$, Refojo MF, Rose J, Synthetic polymers in corneal surgery: glyceryl methacylate, Arch Ophthalmo $1967 ; 177: 52-8$

15. Funderburgh $\mathrm{JL}$, Mann MM, Funderburgh $M \mathrm{~L}$, Keratocyte phenotype mediates proteoglycan structure: a role for fibroblasts in corneal fibrosis, $\mathrm{J} \mathrm{Biol} \mathrm{Chem,}$ 2003;278:45629-37.

16. Tanihara $\mathrm{H}$, Inatani $\mathrm{M}$, Koga $\mathrm{T}$, et al., Proteoglycans in the eye, Cornea, 2002;21:S62-S69.

17. Larrea X, De Courten C, Feingold V, et al., Oxygen and glucose distribution after intracorneal lens implantation, Optom Vis SCi, 2007:84:1074-81.

18. Harvitt $D M$, Bonanno JA, Re-evaluation of the oxygen diffusion model for predicting minimum contact lens DK/ values needed to avoid corneal anoxia, Optom Vis Sci,
1999;76:712-9.

19. Hill RM, Fatt I, Oxygen uptake from a reservoir of limited volume by the human cornea in vivo, science, 1963:142:1295-7.

20. Yilmaz OF, Bayraktar $\mathrm{S}$, Agea A, et al., Intracorneal inlay for the surgical correction of presbyopia, I Cataract Refract Surg, 2008:34:1921-7.

21. Mulet ME, Alio JL, Knorz MC, Hydrogel intracorneal inlays for the correction of hyperopia: outcomes and complications after 5 years of follow-up, Ophthalmology, 2009:116:1455-60

22. Seyeddain $O$, Riha W, Hohensinn M, et al., Refractive surgical correction of presbyopia with the acufocus small aperture corneal inlay: two-year follow-up, J Refract Surg, 2010;26:1-9.

23. Yilmaz $\mathrm{O}$, Alagöz N, Pekel G, et al., Intracorneal inlay to correct presbyopia: Iong-term results, J Cataract Refractive Surg, 2011;37:1275-81.

24. Limnopoulou AN, Bouzoukis DI, Kymionis GD, et al., Visual outcomes and safety of a refractive corneal inlay for presbyopia using femtosecond laser, J Refract Surg, 2013:29:12-18.

25. Chayet A, Barragan Garza E, Combined hydrogel inlay and laser in situ keratomileusis to compensate for presbyopia in hyperopic patients: one-year safety and efficacy, J Cataract hyperopic patients: one-year s1

26. Barragan Garza E, Gomez S, Chayet A, Dishler J, One year safety and efficacy results of a hydrogel inlay to improve nea safety and efficacy results of a hydrogel inlay to improve nea
vision in patients with emmetropic presbyopia, $J$ Refractive vision in patients with 


\section{Some Examples of the Authors' Experience with the Raindrop}

The following are three examples of patients with different refractive statuses that were successfully implanted with the Raindrop. All inlays were implanted under a 150m flap created with the VisuMax ${ }^{\circledR}$ (Carl Zeiss Meditec) and the any LASIK photoablation was performed using the MEL $80^{\mathrm{TM}}$ (Carl Zeiss Meditec). All patients were followed up for a period of at least 1 year. All visual acuities are reported in logMAR notation.

\section{The Pseudophakic Patient}

Female patient, 47 years old

Previous cataract surgery in both eyes

Non-dominant eye: left

Surgery: right PRK and left Raindrop implantation

Refraction:



\begin{tabular}{|c|c|c|c|c|c|c|c|c|c|c|c|}
\hline $\begin{array}{l}\text { Preop. } \\
\text { monocular } \\
\text { UDVA }\end{array}$ & $\begin{array}{l}\text { Postop. } \\
\text { monocular } \\
\text { UDVA }\end{array}$ & $\begin{array}{l}\text { Preop. } \\
\text { monocular } \\
\text { BDVA }\end{array}$ & $\begin{array}{l}\text { Postop. } \\
\text { monocular } \\
\text { BDVA }\end{array}$ & $\begin{array}{l}\text { Preop. } \\
\text { binocular } \\
\text { UDVA }\end{array}$ & $\begin{array}{l}\text { Postop. } \\
\text { binocular } \\
\text { UDVA }\end{array}$ & $\begin{array}{l}\text { Preop. } \\
\text { binocular } \\
\text { BDVA }\end{array}$ & $\begin{array}{l}\text { Postop. } \\
\text { binocular } \\
\text { BDVA }\end{array}$ & $\begin{array}{l}\text { Preop. } \\
\text { monocular } \\
\text { UNVA }\end{array}$ & $\begin{array}{l}\text { Postop. } \\
\text { monocular } \\
\text { UNVA }\end{array}$ & $\begin{array}{l}\text { Preop. } \\
\text { binocular } \\
\text { UNVA }\end{array}$ & $\begin{array}{l}\text { Postop. } \\
\text { binocular } \\
\text { UNVA }\end{array}$ \\
\hline Right: 0.5 & Right: 0.7 & Right: 0.9 & Right: 0.9 & 1.0 & 0.9 & 1.0 & 1.0 & Right: 0.6 & Right: 0.5 & 0.6 & 0.9 \\
\hline Left: 0.9 & Left: 0.8 & Left: 1.0 & Left: 0.9 & & & & & Left: 0.5 & Left: 0.9 & & \\
\hline
\end{tabular}

Male patient, 57 years old

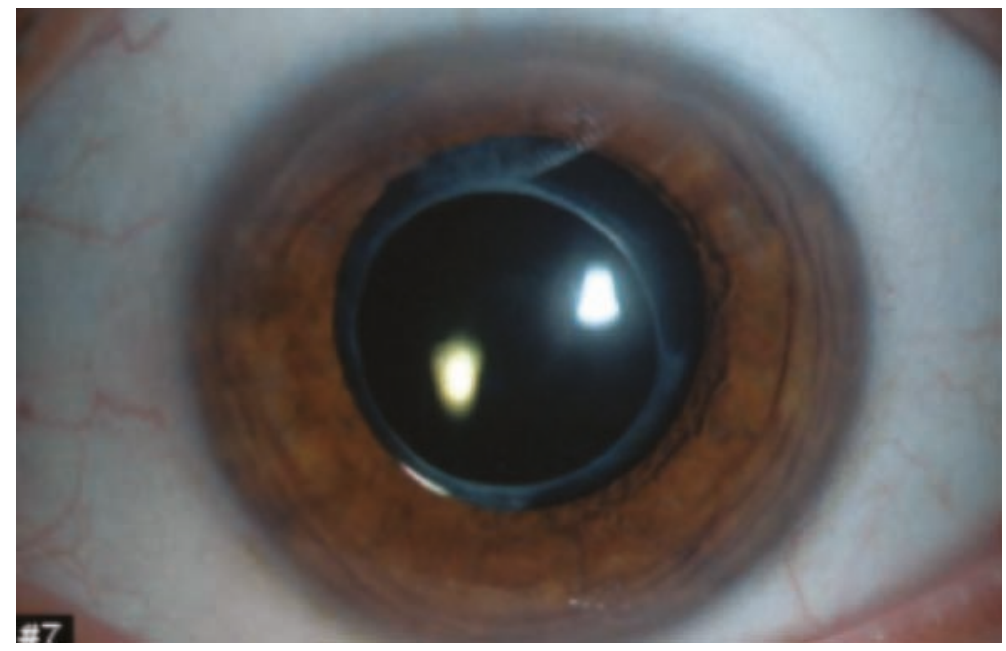

Image 1: Pseudophakic patient with the Raindrop.

Non-dominant eye: left

Surgery: left Raindrop implantation

Refraction:

$\begin{array}{ll}\text { Preop: right: plano } & \text { Left: plano } \\ \text { Postop: right: plano } & \text { Left: }-0.75\end{array}$

\begin{tabular}{|c|c|c|c|c|c|c|c|c|c|c|c|}
\hline $\begin{array}{l}\text { Preop. } \\
\text { monocular } \\
\text { UDVA }\end{array}$ & $\begin{array}{l}\text { Postop. } \\
\text { monocular } \\
\text { UDVA }\end{array}$ & $\begin{array}{l}\text { Preop. } \\
\text { monocular } \\
\text { BDVA }\end{array}$ & $\begin{array}{l}\text { Postop. } \\
\text { monocular } \\
\text { BDVA }\end{array}$ & $\begin{array}{l}\text { Preop. } \\
\text { binocular } \\
\text { UDVA }\end{array}$ & $\begin{array}{l}\text { Postop. } \\
\text { binocular } \\
\text { UDVA }\end{array}$ & $\begin{array}{l}\text { Preop. } \\
\text { binocular } \\
\text { BDVA }\end{array}$ & $\begin{array}{l}\text { Postop. } \\
\text { binocular } \\
\text { BDVA }\end{array}$ & $\begin{array}{l}\text { Preop. } \\
\text { monocular } \\
\text { UNVA }\end{array}$ & $\begin{array}{l}\text { Postop. } \\
\text { monocular } \\
\text { UNVA }\end{array}$ & $\begin{array}{l}\text { Preop. } \\
\text { binocular } \\
\text { UNVA }\end{array}$ & $\begin{array}{l}\text { Postop. } \\
\text { binocular } \\
\text { UNVA }\end{array}$ \\
\hline Right: 1.0 & Right: 1.0 & Right: 1.0 & Right: 1.0 & 1.0 & 1.0 & 1.0 & 1.0 & Right: 0.5 & Right: 0.5 & 0.6 & 1.0 \\
\hline Left: 1.0 & Left: 0.3 & Left: 1.0 & Left: 1.0 & & & & & Left: 0.5 & Left: 1.0 & & \\
\hline
\end{tabular}



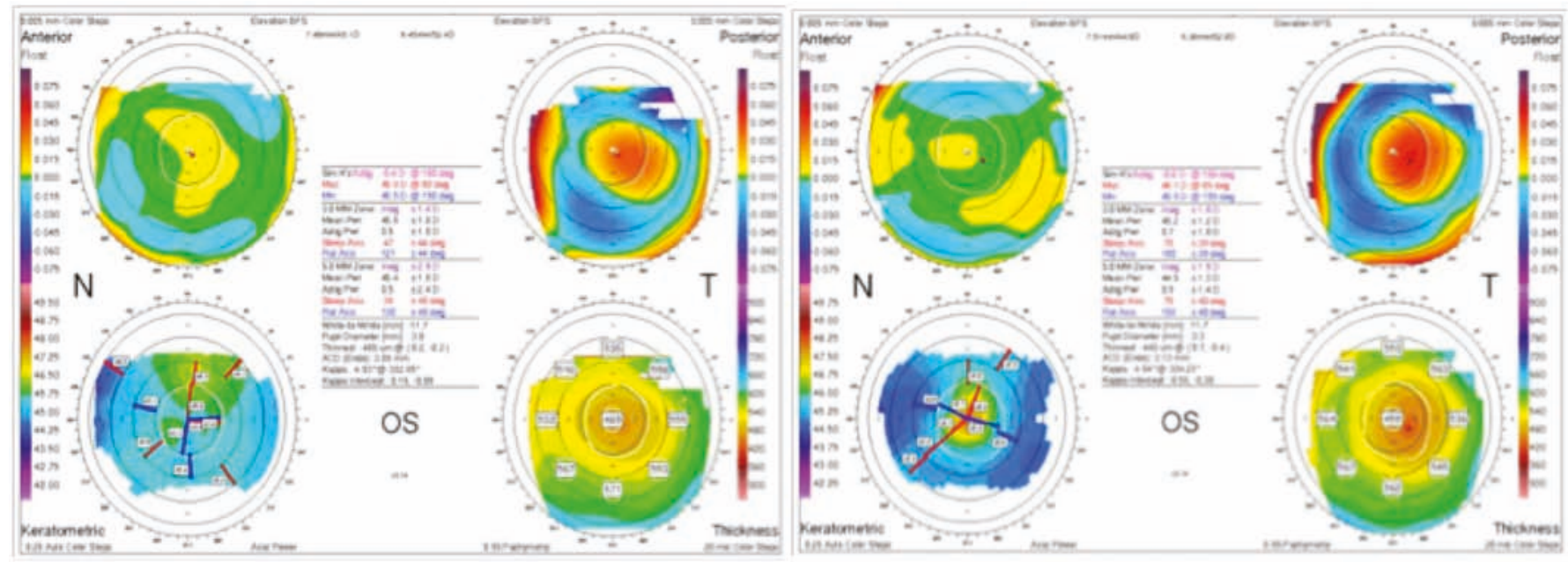

Image 2 and 3: Topography of the left eye before and after Raindrop implantation
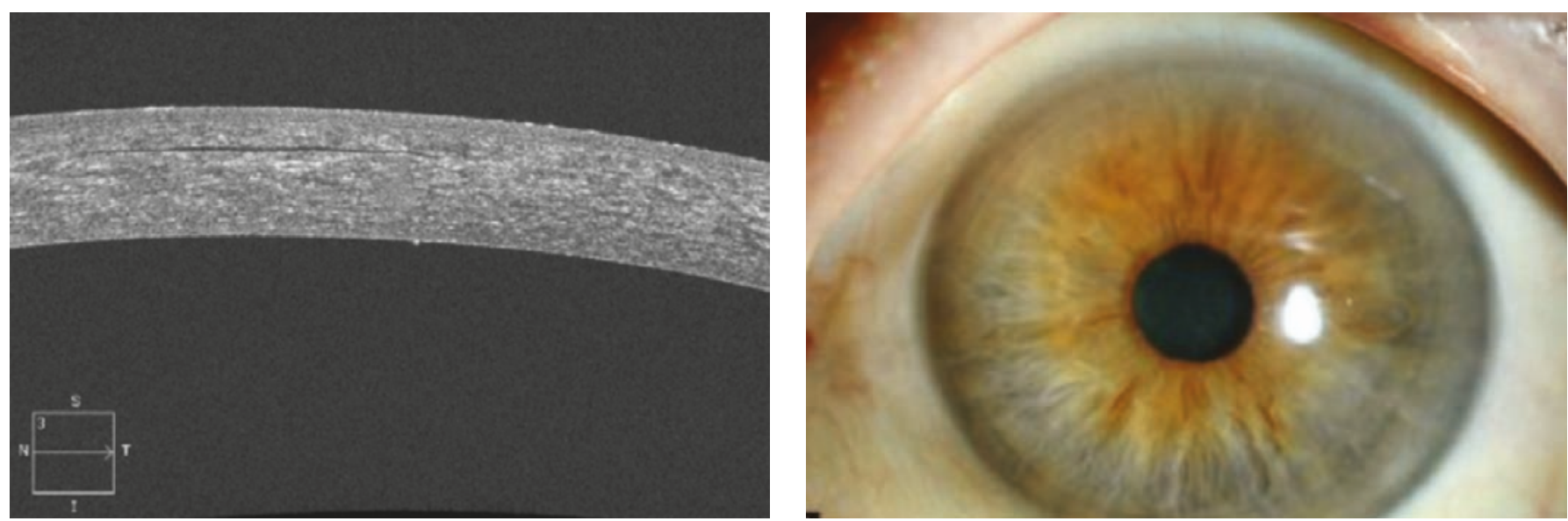

Image 4: Anterior segment optical coherence tomography of the Raindrop in vivo. The uncorrected near visual acuity in the eye implanted with the Raindrop improved dramatically and the uncorrected distance visual acuity (UDVA) in that eye dropped markedly. Binocular

Image 5: Anterior segment photography of the Raindrop in vivo.

The Myopic Patient

Male patient, 47 years old

Non-dominant eye: right

Surgery: right LASIK + Raindrop implantation, Left LASIK

Refraction:

$\begin{array}{ll}\text { Preop: Right }-6.77 /-1.25 \times 145^{\circ} & \text { Left: }-6.75 /-1.0 \times 50^{\circ} \\ \text { Postop: Right }-2 /-0.5 \times 140^{\circ} & \text { Left: }-0.5\end{array}$

\begin{tabular}{|c|c|c|c|c|c|c|c|c|c|c|c|}
\hline $\begin{array}{l}\text { Preop. } \\
\text { monocular } \\
\text { UDVA }\end{array}$ & $\begin{array}{l}\text { Postop. } \\
\text { monocular } \\
\text { UDVA }\end{array}$ & $\begin{array}{l}\text { Preop. } \\
\text { monocular } \\
\text { BDVA }\end{array}$ & $\begin{array}{l}\text { Postop. } \\
\text { monocular } \\
\text { BDVA }\end{array}$ & $\begin{array}{l}\text { Preop. } \\
\text { binocular } \\
\text { UDVA }\end{array}$ & $\begin{array}{l}\text { Postop. } \\
\text { binocular } \\
\text { UDVA }\end{array}$ & $\begin{array}{l}\text { Preop. } \\
\text { binocular } \\
\text { BDVA }\end{array}$ & $\begin{array}{l}\text { Postop. } \\
\text { binocular } \\
\text { BDVA }\end{array}$ & $\begin{array}{l}\text { Preop. } \\
\text { monocular } \\
\text { UNVA }\end{array}$ & $\begin{array}{l}\text { Postop. } \\
\text { monocular } \\
\text { UNVA }\end{array}$ & $\begin{array}{l}\text { Preop. } \\
\text { binocular } \\
\text { UNVA }\end{array}$ & $\begin{array}{l}\text { Postop. } \\
\text { bBinocular } \\
\text { UNVA }\end{array}$ \\
\hline Right: 0.5 & Right: 1.0 & Right: 1.0 & Right: 1.0 & 1.0 & 1.0 & 1.0 & 1.0 & Right: 0.5 & Right: 0.5 & 0.6 & 1.0 \\
\hline Left: 0.5 & Left: 0.3 & Left: 1.0 & Left: 1.0 & & & & & Left: 0.5 & Left: 1.0 & & \\
\hline
\end{tabular}

PRK = photorefractive keratectomy; BDVA = binocular distance visual acuity; LASIK = laser-assisted in situ keratomileusis; UDVA = uncorrected distance visual acuity; UNVA = uncorrected near visual acuity. 


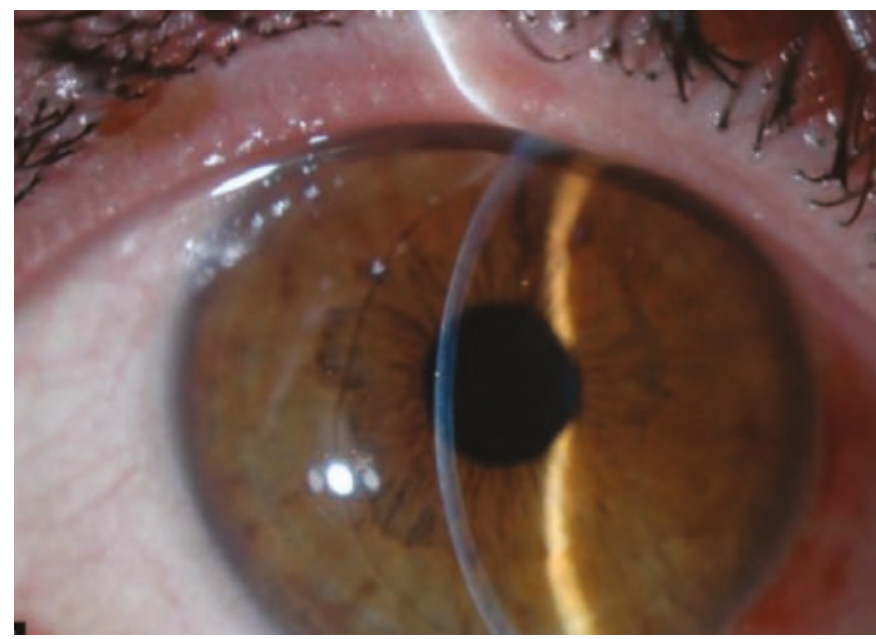

Image 6: Anterior segment photo of the Raindrop in vivo (note how barely visible the inlay is).

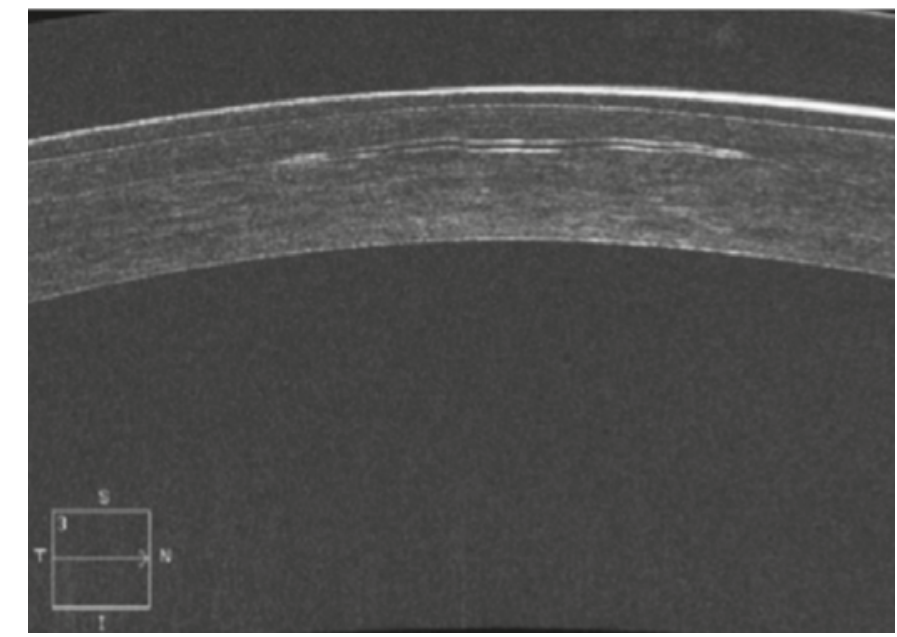

Image 7: Anterior segment optical coherence tomography of the Raindrop in vivo.

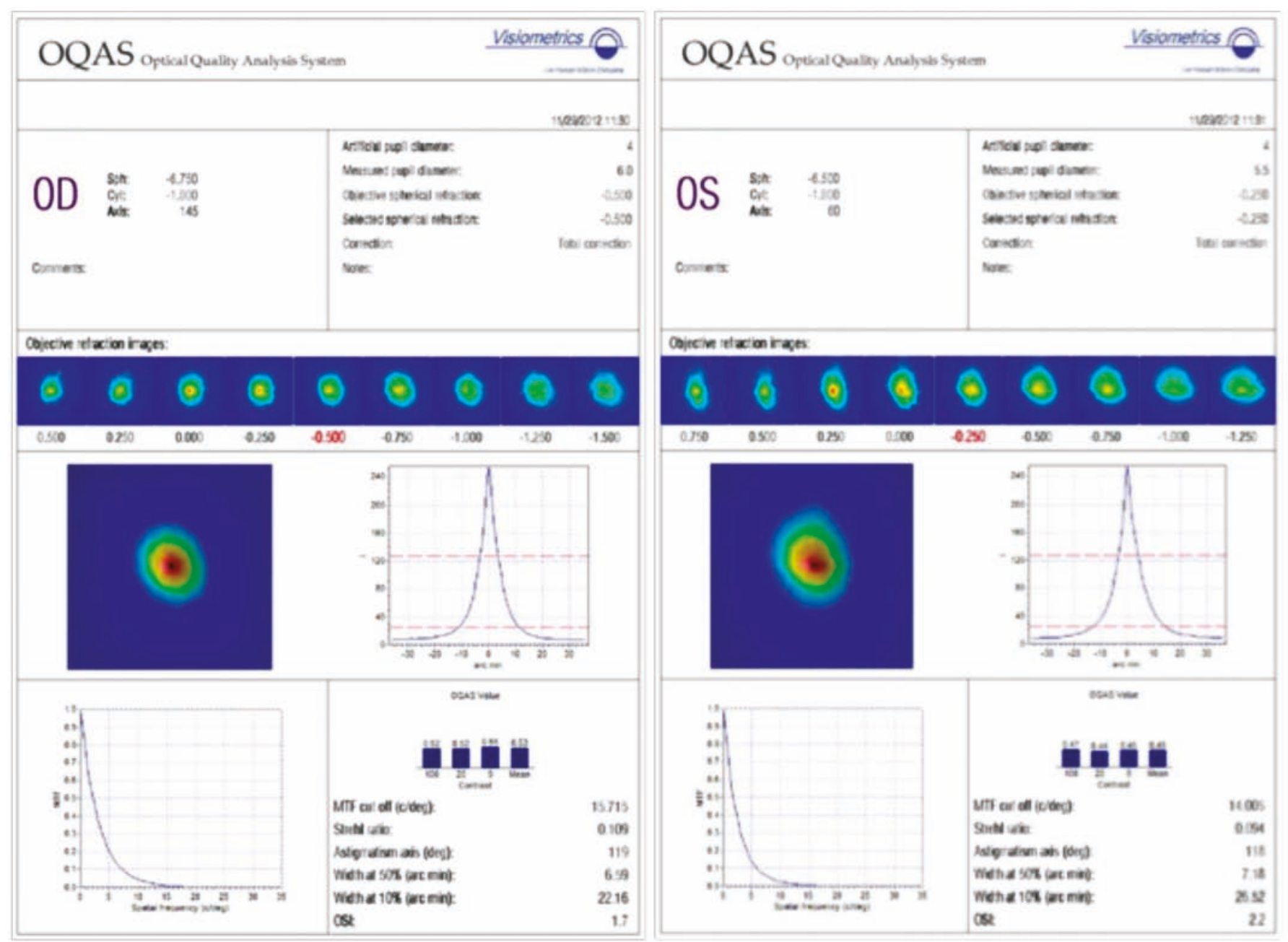

Image 8 and 9 showing modulation transfer function (MTF) with optical clearing agents (OQAS) in both the right eye with the Raindrop and the left eye without. The intended post-laser-assisted in situ keratomileusis (LASIK) refraction in the eye scheduled to receive the inlay was plano. The authors' experience with the Raindrop is that the marked decrease in uncorrected distance visual acuity (UDVA) and the myopic shift witnessed post inlay implantation is usually transit, and the patient's UDVA improves over a period of several months. 